\section{Mowing Height, Nitrogen Rate, and Biostimulant Influence Root Development of Field-grown 'TifEagle' Bermudagrass}

\author{
Brian J. Tucker, ${ }^{1}$ Lambert B. McCarty, ${ }^{2}$ Haibo Liu, ${ }^{3}$ and \\ Christina E. Wells ${ }^{4}$ \\ Department of Horticulture, E-143 Poole Agricultural Center, Clemson \\ University, Clemson, SC 29634-0319
}

James R. Rieck ${ }^{5}$

Department of Applied Economics and Statistics, 104 Poole Agricultural Center, Clemson University, Clemson, SC 29634-0375

Additional index words. 'TifEagle' bermudagrass, Cynodon dactylon (L.) Pers. $\times$ C. transvaalensis Burtt-Davy, golf courses, golf greens, putting greens, ultradwarf bermudagrass

\begin{abstract}
As golfers demand higher quality golf green putting surfaces, researchers continue to seek improved turfgrass cultivars. One such improved cultivar is 'TifEagle' bermudagrass [Cynodon dactylon (L.) Pers. $\times$ C. transvaalensis Burtt-Davy], which is an improvement over traditional bermudagrass cultivars such as 'Tifgreen' and 'Tifdwarf' due to its ability to tolerate mowing heights of $\leq 3.2 \mathrm{~mm}$ for extended periods. One observed disadvantage of 'TifEagle' is its lack of a deep, dense root system compared to previous bermudagrass cultivars. This field study measured mowing height, $\mathrm{N}$ rate, and biostimulant product effects on 'TifEagle' rooting. Three mowing heights $(3.2,4.0$, and $4.8 \mathrm{~mm})$, three $\mathrm{N}$ rates $(12,24$, and $48 \mathrm{~kg} \mathrm{~N} / \mathrm{ha} /$ week), and two cytokinin-containing commercial biostimulant products (BIO1 and $\mathrm{BIO2}$ ) were examined. Plant responses measured were root length density (RLD), root surface area (RSA), thatch layer depth (TLD), and turf quality (TQ). Increasing mowing height from 3.2 to $4.0 \mathrm{~mm}$ increased RLD by $>11 \%$, RSA by $>11 \%$, and TQ by $>17 \%$. Increasing $\mathrm{N}$ rates from 12 to $24 \mathrm{~kg} \mathrm{~N} \mathrm{ha}^{-1}$ week $^{-1}$ increased RLD by $>17 \%$, RSA by $>26 \%$ and TQ by $>16 \%$. No effect on RLD was observed after the first year of biostimulant use, however, after the second year, BIO1 increased RLD by $>11 \%$ when applied with the lowest rate of $N(12 \mathrm{~kg} \mathrm{~N} / \mathrm{ha} /$ week $)$. Higher mowing heights $(4.8$ and $4.0 \mathrm{~mm})$ increased TLD $>6 \%$ compared to the lowest mowing height $(3.2 \mathrm{~mm}$ ), and higher $\mathrm{N}$ rates (48 and $24 \mathrm{~kg} \mathrm{~N} / \mathrm{ha} /$ week) increased TLD $>3 \%$ compared to the lowest $N$ rate $(12 \mathrm{~kg} \mathrm{~N} / \mathrm{ha} /$ week). Overall, a mowing heights $\geq 4.0 \mathrm{~mm}, \mathrm{~N}$ rates $\geq 24$ $\mathrm{kg} \mathrm{N} / \mathrm{ha}$ /week, and long-term use of a cytokinins-containing biostimulant had a positive effect on 'TifEagle' rooting.
\end{abstract}

Newer dwarf bermudagrasses such as 'TifEagle' produce a higher quality turf under low mowing heights and retain better color under cooler conditions (McCarty, 2005). 'TifEagle' bermudagrass provides a superior playing surface compared the previous industry standards, 'Tifgreen' and 'Tifdwarf,' when mowing at heights of $\leq 3.2 \mathrm{~mm}$ for extended periods (Hanna, 1998). 'TifEagle' bermudagrass appears to have several advantages over its predecessors, but additional research on the best management practices for 'TifEagle'

\footnotetext{
Received for publication 11 Nov. 2005. Accepted for publication $2 \mathrm{Feb}$. 2006. Technical Contribution No. 5174 of the Clemson University Experiment Station. Research conducted at Clemson University, Clemson, SC. Use of trade names does not imply endorsement of the products named nor criticism of similar ones not named.

1'E-mail btucker@clemson.edu.

${ }^{2}$ To whom reprints requests should be addressed; e-mailbmccrty@clemson.edu.

3E-mail haibol@clemson.edu.

4E-mail cdwells@clemson.edu.

5E-mail jrieck@clemson.edu.
}

Hybrid bermudagrass cultivars exhibit increased shoot growth and improved turf quality in response to $\mathrm{N}$ fertilization(Trenholm et al., 1998). Root growth has been shown to suffer due to excessive shoot growth in various turf species (Adams et al., 1974). Yet, some hybrid bermudagrass cultivars have shown an increase in rooting under higher $\mathrm{N}$ levels. 'Santa Ana,' 'FloraDwarf,' and 'Tifgreen' bermudagrass demonstrate increases in root length as a response to increasing $\mathrm{N}$ under certain conditions (Horst, 1985; Snyder and Cisar, 2000; Trenholm et al., 1998). Bunnell et al. (2005) noted that increasing mowing height and $\mathrm{N}$ rates increased 'TifEagle' bermudagrass tolerance to shade. Understanding how 'TifEagle' bermudagrass responds to $\mathrm{N}$ and mowing height is critical to maintaining a healthy root system.

Biostimulants are plant hormone-containing substances that can stimulate growth when exogenously applied (Schmidt, 1992). Biostimulant products have great potential in the turfgrass industry if they actually enhance root and shoot growth under field conditions. The addition of exogenous plant hormones can increase antioxidant activity in cool season grasses, as well as improve drought and heat tolerance in growth chamber studies (Liu et al., 2002; Zhang and Schmidt, 1999). The effect of biostimulants on 'TifEagle' bermudagrass is not clearly understood.

The objectives of this study were to examine the effect of mowing height, $\mathrm{N}$ rates, and cytokinin-containing biostimulants on 'TifEagle' bermudagrass root growth.

\section{Materials and Methods}

This study was conducted on the 'TifEagle' research plots at Clemson University in Clemson, SC. The green was sprigged in June 1999 with $115 \mathrm{~m}^{2} \cdot \mathrm{ha}^{-1}$ certified 'TifEagle' bermudagrass. Soil profile construction and soil physical properties followed USGA recommendations with a 85 sand : 15 peat (by volume) mix (USGA, 1993) The study was conducted from 1 July to 31 Aug. 2002 and repeated in 2003. The study consisted of 81 individual plots $1 \mathrm{~m}$ wide $\times 1 \mathrm{~m}$ long. Each study lasted 8 weeks. The entire study was aerified in June using $16 \mathrm{~mm}$ hollow tines with cores removed thereafter.

Three mowing heights $(3.2,4.0$, and 4.8 $\mathrm{mm})$ were maintained with three separate reel mowers (model 220A; Deere and Company, Moline, Ill.) and mowed $6 \mathrm{~d} /$ week. Three N rates were applied in this study. All plots received a greens-grade $18 \mathrm{~N}-3.9 \mathrm{P}-15 \mathrm{~K}(50 \%$ water insoluble N) fertilizer at a rate of $12 \mathrm{~kg}$ $\mathrm{N} / \mathrm{ha}$ /week using a rotary spreader in two directions to ensure uniform distribution. Additional $\mathrm{N}$ treatments received ammonium sulfate $(21 \mathrm{~N}-0 \mathrm{P}-0 \mathrm{~K})$ at 12 and $36 \mathrm{~kg} \mathrm{~N} / \mathrm{ha} /$ week, providing a total rate of 24 and $48 \mathrm{~kg} \mathrm{~N} / \mathrm{ha} /$ week, respectively. Ammonium sulfate applications were made by hand in two directions. Nitrogen treatments were irrigated immediately following application with about $6.4 \mathrm{~mm}$ of water. Irrigation was applied throughout the study to maintain adequate moisture. 
Biostimulant treatments consisted of Panasea Plus (BIO1) $(0 \mathrm{~N}-1.3 \mathrm{P}-1.7 \mathrm{~K})$ (Emerald Island Ltd., Ann Arbor, Mich.) applied at the manufacturer's recommended rate of 12.7 $\mathrm{L} \cdot \mathrm{ha}^{-1}$ every 4 weeks, or Plant N.O.G. (BIO2) (Senn, Sharman, and Senn, LLC, Clemson, S.C.) at a rate of $6.35 \mathrm{~L} \cdot \mathrm{ha}^{-1}$ every 2 weeks. Panasea Plus is a liquefied sea plant extract with labeled claims to deliver hormones, nutrients, and trace elements to turfgrasses. The active ingredient listed on the Plant N.O.G. label is a cytokinin (kinetin) at $0.01 \%$ of the total concentration. Biostimulant applications were made with a $\mathrm{CO}_{2}$ backpack sprayer calibrated at $187 \mathrm{~L} \cdot \mathrm{ha}^{-1}$ and a $1-\mathrm{m}$ hooded-boom to minimize drift.

Measurements. To ascertain root growth, two samples, $5 \mathrm{~cm}$ diameter $\times 30 \mathrm{~cm}$ deep, were removed from each plot using a root auger at the conclusion of each yr (31 August) of the 2-year study. Root samples were separated, washed, and collected using a 1-mm sieve. Roots were separated from below the thatch layer, and the thatch layer depth (TLD) was recorded using a caliper. Roots from each plot were scanned and analyzed using WinRhizo (Regent Instruments Inc., Quebec, Qc, Canada) software to determine root length density (RLD) and root surface area (RSA). WinRhizo provides a computerized method of measuring RLD as described by Tennant (1975). This measured the total root length $(\mathrm{mm})$ per volume of soil $\left(\mathrm{cm}^{3}\right)$. Root surface area measured the total surface area $\left(\mathrm{cm}^{2}\right)$ of the root system in each $5 \times 30 \mathrm{~cm}$ soil core. Visual turfgrass quality (TQ) ratings were made weekly on a 1 to 9 scale and averaged over the 8-week study. Turfgrass with a rating of 9 had exceptional color and density, while 1 was considered dead turf, and 7 was minimally acceptable.

Statistical design and analysis. The study was a split plot design with whole plots arranged in a Latin square. Nitrogen rate and biostimulant were the subplot factors, and mowing height was the whole plot factor. Three mowing heights, three $\mathrm{N}$ rates, and two biostimulants were examined in this study. Treatments were replicated three times. The study was analyzed using repeated measures analysis of variance (PROC SAS MIXED) (SAS Institute, 1987) for all calculations. Mean separations for treatment effects were performed using Fisher's protected LSD at the $\alpha=0.10$ level for below ground measurements and $\alpha=0.05$ for turf quality. Mowing height interactions with $\mathrm{N}$ or biostimulants were not detected, however main effect of mowing height was significant. Year by $\mathrm{N}$ by biostimulant interaction was detected and thus biostimulant effects were analyzed separately by year and $\mathrm{N}$ rate.

\section{Results}

Plant responses are reported as individual treatment means for mowing height, $\mathrm{N}$ rate, and biostimulant effects on TQ, TLD, RLD, and RSA, and TLD.

Turf quality. Increasing mowing height and $\mathrm{N}$ rate improved TQ (Table1). The two higher mowing heights (4.0 and $4.8 \mathrm{~mm}$ ) had an average TQ of 8.0, while the lowest mowing height $(3.2 \mathrm{~mm})$ had an average TQ below the acceptable level (7.0). The two higher $\mathrm{N}$ rates (48 and $24 \mathrm{~kg} \mathrm{~N} / \mathrm{ha} /$ week) had an average TQ $>7.8$, while the lowest $\mathrm{N}$ rate $(12 \mathrm{~kg}$ $\mathrm{N} /$ ha/week) had unacceptable quality. Neither biostimulant influenced TQ.

Thatch layer depth. TLD increased in response to mowing height and $\mathrm{N}$ rate (Table $1)$. The two higher mowing heights (4.8 and $4.0 \mathrm{~mm}$ ) increased TLD by $>6 \%$. The two higher $\mathrm{N}$ rates $(24$ and $48 \mathrm{~kg} \mathrm{~N} /$ ha/week) increased TLD by $>3 \%$ compared to lowest rate (12 kg N/ha/week). Biostimulant use did not influence TLD.

Root surface area. Mowing height and $\mathrm{N}$ rate both influenced RSA(Table 1). The highest mowing height $(4.8 \mathrm{~mm})$ had $>18 \%$ more RSA than treatments mowed at $3.2 \mathrm{~mm}$, and the 4.0 mm mowing height had $>11 \%$ more RSA than the $3.2 \mathrm{~mm}$ mowing height. The two highest $\mathrm{N}$ rates ( 24 and $48 \mathrm{~kg} \mathrm{~N} / \mathrm{ha} /$ week) had $>21 \%$ more RSA than the lowest rate $(12 \mathrm{~kg} \mathrm{~N} / \mathrm{ha} /$ week $)$. Biostimulant use did not influence RSA.

Root length density. Mowing height, N rate, and use of a biostimulant influenced RLD (Table1). The two higher mowing heights (4.0 and $4.8 \mathrm{~mm}$ ) increased RLD by $>11 \%$ compared to the $3.2 \mathrm{~mm}$ mowing height. An increase in RLD of $>17 \%$ was observed following 8 weeks of 24 and $48 \mathrm{~kg} \mathrm{~N} / \mathrm{ha} /$ week compared to treatments receiving $12 \mathrm{~kg} \mathrm{~N} / \mathrm{ha} /$ week. If each year is examined separately (Table 2), a significant increase in RLD occurred with BIO1 when the biostimulant was applied to treatments receiving $12 \mathrm{~kg} \mathrm{~N} / \mathrm{ha} /$ week in 2003. After 2 years of use, RLD was increased $>11 \%$ by BIO 1 compared to nonbiostimulant treatments. No biostimulant by $\mathrm{N}$ interaction occurred at the higher $\mathrm{N}$ rates.

\section{Discussion}

Mowing height and $\mathrm{N}$ rate influenced TQ, TLD, RSA and RLD in the field. The lowest $\mathrm{N}$ rate (12 kg N/ha/week) produced unacceptable quality while bermudagrass quality from other $\mathrm{N}$ rates was acceptable. The two higher mowing heights ( 4.0 and $4.8 \mathrm{~mm}$ ) were more beneficial to 'TifEagle' rooting than the lowest (3.2 mm) mowing height. Higher mowing heights increased RLD $>10 \%$ and TLD $>6 \%$ compared to the $3.2 \mathrm{~mm}$ mowing height. Lowering the mowing height of turfgrasses reduces new root production and rooting depth and increases root mortality and turnover rate (Liu and Huang, 2002). In a 2-year creeping bentgrass (Agrostis palustris Huds.) study, root biomass was $32 \%$ greater in turf maintained at $4.8 \mathrm{~mm}$, and $36 \%$ greater in turf maintained at $4.0 \mathrm{~mm}$ when compared with $3.2 \mathrm{~mm}$ mowing height (Fagerness and Yelverton, 2001). In a TifEagle bermudagrass study, highest turf quality occurred when it received 12 or $8 \mathrm{~h}$ full sunlight, was mowed at $4.7 \mathrm{~mm}$ compared to $3.2 \mathrm{~mm}$, additional $\mathrm{N}$ of $24.5 \mathrm{~kg} \mathrm{~N} / \mathrm{ha}$ was made every 2 weeks, and certain gibberellic acid-inhibiting plant growth retardants were used (Bunnell et al., 2005).

Nitrogen rates also had a significant effect on RLD. The higher rates ( 24 and $48 \mathrm{~kg} \mathrm{~N} / \mathrm{ha} /$ week) increased RLD by $>17 \%$ and TLD $>3 \%$ compared to the lowest $\mathrm{N}$ rate $(12 \mathrm{~kg} \mathrm{~N} / \mathrm{ha} /$ week). Snyder and Cisar (2000) concluded that after 1 year, increased $\mathrm{N}$ rates increased root mass in 'Tifgreen'bermudagrass, but following the first year, differences were not detected. Root growth also increased in 'Santa Ana' and 'FloraDwarf' bermudagrass in response to $\mathrm{N}$ (Horst et al., 1985; Trenholm et al., 1998). Sny-

Table 1. Two-year combined effect of mowing height and $\mathrm{N}$ rate on the turf quality (TQ), thatch layer depth (TLD), root length density (RLD), and root surface area (RSA) of field-grown 'TifEagle' bermudagrass after 8 weeks.

\begin{tabular}{lcccc}
\hline & \multicolumn{4}{c}{ Plant response $^{z}$} \\
\cline { 2 - 5 } Treatment & $\begin{array}{c}\mathrm{TQ}^{\mathrm{x}} \\
(1-9)\end{array}$ & $\begin{array}{c}\text { TLD } \\
(\mathrm{mm})\end{array}$ & $\begin{array}{c}\text { RSA } \\
\left(\mathrm{cm}^{2}\right)\end{array}$ & $\begin{array}{c}\text { RLD } \\
\left(\mathrm{mm} \cdot \mathrm{cm}^{-3}\right)\end{array}$ \\
\hline Mowing height & & & & \\
$\quad 3.2$ & $6.8 \mathrm{~b}$ & $27.9 \mathrm{~b}$ & $272 \mathrm{c}$ & $32.8 \mathrm{~b}$ \\
4.0 & $8.0 \mathrm{a}$ & $29.8 \mathrm{a}$ & $302 \mathrm{~b}$ & $36.4 \mathrm{a}$ \\
$\quad 4.8$ & $8.0 \mathrm{a}$ & $30.1 \mathrm{a}$ & $320 \mathrm{a}$ & $37.7 \mathrm{a}$ \\
Nitrogen rate & & & & \\
$\quad 6.8 \mathrm{c}$ & $28.3 \mathrm{~b}$ & $257 \mathrm{~b}$ & $31.8 \mathrm{~b}$ \\
24 & $7.9 \mathrm{~b}$ & $29.4 \mathrm{a}$ & $325 \mathrm{a}$ & $37.4 \mathrm{a}$ \\
48 & $8.1 \mathrm{a}$ & $30.1 \mathrm{a}$ & $312 \mathrm{a}$ & $37.6 \mathrm{a}$ \\
\hline
\end{tabular}

${ }^{2}$ Means followed by the same letter are not significantly different according to Fisher's protected LSD ( $\alpha$ $=0.10$ for below ground measurements and $\alpha=0.05$ for TQ) test.

y Mowing heights are measured in $\mathrm{mm}$, and $\mathrm{N}$ rates are measured in $\mathrm{kg} \mathrm{N} / \mathrm{ha} /$ week.

${ }^{x}$ TQ was visually rated weekly using a scale of 1 to 9 and averaged over the 8 -week study. Turfgrass with a rating of 9 had exceptional color and density, while 1 was considered dead turf, and 7 was minimally acceptable.

Table 2. Yearly effect of biostimulants on the root length density (RLD) of field-grown 'TifEagle' bermudagrass after 8 weeks.

\begin{tabular}{lccc}
\hline & & \multicolumn{2}{c}{ Root length density $^{\mathrm{z}}\left(\mathrm{mm} \cdot \mathrm{cm}^{-3}\right)$} \\
\cline { 3 - 4 } Biostimulant $^{\mathrm{y}}$ & $\mathrm{N}$ rate & 2002 & 2003 \\
\hline None & 12 & $37.8 \mathrm{a}$ & $30.5 \mathrm{~b}$ \\
BIO1 & 12 & $39.8 \mathrm{a}$ & $34.1 \mathrm{a}$ \\
BIO2 & 12 & $40.3 \mathrm{a}$ & $30.0 \mathrm{~b}$ \\
\hline
\end{tabular}

${ }^{2}$ Means followed by the same letter are not significantly different according to Fisher's protected LSD ( $\alpha$ $=0.10)$ test.

${ }^{\mathrm{y}}$ Biostimulant applications were applied at a total rate of $12.7 \mathrm{~L}$ of product $/ \mathrm{ha} / \mathrm{month}$. $\mathrm{BIO} 1$ and $\mathrm{BIO} 2$ are two cytokinin-containing commercial biostimulant products. 
der and Cisar (2000) also reported an increase in thatch layer depth with increasing $\mathrm{N}$ rates. Higher $\mathrm{N}$ rates (24 and $48 \mathrm{~kg} \mathrm{~N} / \mathrm{ha} /$ week) in this study also significantly increased RSA by $>21 \%$ in treatments compared to those receiving the lowest rate of $\mathrm{N}$ (12 kg N/ha/week). Mowing height also influenced RSA, 4.8 and $4.0 \mathrm{~mm}$ had $>11 \%$ more RSA than the $3.2 \mathrm{~mm}$ mowing height.

Cytokinin-containing biostimulant products have potential to increase turfgrass rooting. This potential appears greatest when turf is grown on sand-based soils, under environmental or physiological stress, or when certain growth parameters, such as $\mathrm{N}$, are restricted (McCarty, 2005). Recent research conducted on creeping bentgrass concludes that when applied under heat stress conditions, cytokinin can increase root mass and turf quality in creeping bentgrass (Liu et al., 2002). In our study, a cytokinins-containing biostimulant product demonstrated this potential by increasing bermudagrass RLD by $>11 \%$ when applied to treatments receiving the lowest rate of $\mathrm{N}(12 \mathrm{~kg} \mathrm{~N} / \mathrm{ha} /$ week), although 2 years of use were necessary to achieve these results. Therefore, biostimulants effects on 'TifEagle' bermudagrass rooting is an area that warrants further investigations with cultural practices that influence growth and development. Overall, higher mowing heights, sufficient but not excessive $\mathrm{N}$ rates, and long term use of a cytokinin containing biostimulant are beneficial to 'TifEagle' bermudagrass rooting.

\section{Literature Cited}

Adams, W.E., P.J. Bryan, and G.E. Walker. 1974 Effects of cutting height and nitrogen on growth pattern of turfgrasses, p. 131-144. In: E.C. Roberts (ed.). Proc 2nd Int. Turfgrass Res. Conf., Blacksburg, Va., 19-21 June 1973, ASA-CSSA, Madison, Wis.

Bunnell, B.T., L.B. McCarty, and W.C. Bridges. 2005. 'Tifeagle' bermudagrass response to growth factors and mowing heights when grown at various hours of sunlight. Crop Sci. 45:575-581.

Fagerness, M.J. and F.H. Yelverton. 2001. Plant growth regulator and mowing height effects on seasonal root growth of 'Penncross' creeping bentgrass. Crop Sci. 41:1901-1905.

Hanna, W. 1998. The future of bermudagrass. Golf Course Mgt. 66:49-52.

Horst, G.L., L.B. Fenn, and N.B. Dunning. 1985. Bermudagrass turf responses to nitrogen sources. J. Amer. Soc. Hort. Sci. 110:759-761.

Liu, X. and B. Huang. 2002. Mowing effects on root production, growth, and mortality of creeping bentgrass. Crop Sci. 42:1241-1250.

Liu, X., B. Huang, and G. Banowetz. 2002. Cytokinin effects on creeping bentgrass responses to heat stress: I. Shoot and root growth. Crop Sci. 42:457-465.

McCarty, L.B. 2005. Best golf course management practices. 2nd ed. Prentice Hall., Upper Saddle River, N.J.

Schmidt, R.E. 1992. Biostimulants. Grounds Maintenance. 27:38-56.

Snyder, G.H. and J.L. Cisar. 2000. Nitrogen/potassium fertilization ratios for bermudagrass turf. Crop Sci. 40:1719-1723.

Tennant D. 1975. A test of a modified line intersect method for estimating root length. J. Ecol. 63:995-1001.

Trenholm, L.E., A.E. Dudeck, J.B. Sartain, and J.L. Cisar. 1998. Bermudagrass growth, total nonstructural carbohydrate concentration, and quality as influenced by nitrogen and potassium. Crop Sci. 38:168-174.

Zhang, X. and R.E. Schmidt. 1999. Antioxidant response to hormone-containing product in Kentucky bluegrass subjected to drought. Crop Sci. 39:545-546.

Zhang, X., R.E. Schmidt, E.H. Ervin, and S. Doak. 2002. Creeping bentgrass physiological responses to natural plant growth regulators and iron under two regimes. HortScience $37: 898-902$. 